
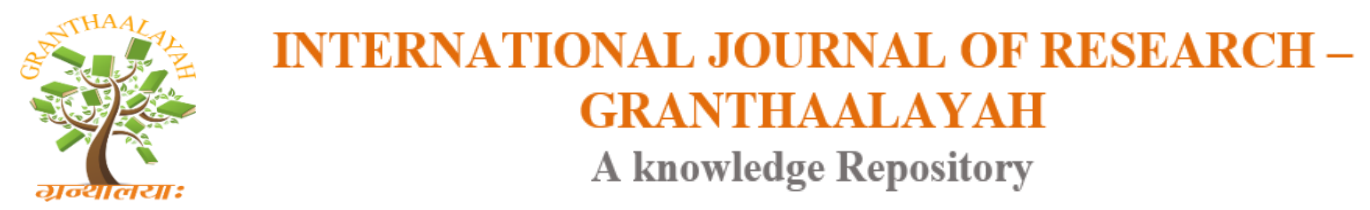

Management

\title{
A STUDY ON INTER-STATE DISPARITIES IN PUBLIC HEALTH EXPENDITURE AND ITS EFFECTIVENESS ON HEALTH STATUS IN INDIA
}

\author{
Dr.L.Ganesan ${ }^{* 1}$, R. Senthamizh Veena ${ }^{2}$ \\ ${ }^{1}$ Professor \& Head, Department of Economics, Bharathidasan University, Tiruchirappalli, \\ Tamil Nadu, India \\ ${ }^{2}$ Rajiv Gandhi National Research Fellow, Department of Economics, Bharathidasan University, \\ Tiruchirappalli, Tamil Nadu, India
}

\begin{abstract}
Public health services play an important role in the health status of the people and Health Expenditure by the Government occupies crucial part in influencing the health outcome in the country. The healthcare finances are influenced by the respective State's budgetary allocation which leads to inter-state disparity in health services and health status in India. This has implications on providing Universal Health Coverage, which aims at ensuring equitable health services to people at all levels in the country (National Health Portal, GoI). The researcher has selected 15 major states based on the level of population (which accounts for about 90 percent of the total population in India) to analyse the inter-state disparities in health sector. Alongside, this study focuses on the performance of public health sector of the selected states through a comparative analysis of various parameters depicting health expenditure, availability of health services, their utilization and health outcomes. With vast variation in the availability, affordability and utilisation of health services across different states, it is found that the economic conditions, health finance, infrastructure and effectiveness of health services at the state level have direct bearing on the health status of the people in the respective states. Therefore, it is essential to take necessary corrective measures that target the disparity, to achieve better and equitable health services for all, leading to Universal Health Coverage which is the real inclusiveness.
\end{abstract}

Keywords: Public Health Services in India; Health Expenditure; Health Infrastructure; Inter-State Disparitie; Universal Health Coverage.

Cite This Article: Dr.L.Ganesan, and R. Senthamizh Veena. (2018). "A STUDY ON INTERSTATE DISPARITIES IN PUBLIC HEALTH EXPENDITURE AND ITS EFFECTIVENESS ON HEALTH STATUS IN INDIA.” International Journal of Research - Granthaalayah, 6(2), 54-64. https://doi.org/10.5281/zenodo.1186108. 


\section{Introduction}

Public Health Services play an important role in the health status of the people and Public Health Financing is one of the critical determinants that influence health outcomes in a country. In India, health being the State's responsibility the healthcare finances are influenced by the respective State's budgetary allocation. Consequently, inter-state disparity in availability and utilization of public health services arises. This has implications on providing Universal Health Coverage, which aims at 'ensuring equitable access for all Indians throughout the country to provide affordable, accountable and appropriate health services of assured quality with the government being the guarantor and enabler' (National Health Portal, GoI). Therefore, it is essential to study the differences in health services among the states which would assist to reduce the differences and make the health sector equitable in the country.

\section{Objectives}

- To make a comparative study and identify the variations in health expenditure and health status in the selected states in India.

- To study the differences in availability and utilization pattern of public health services among the states.

- To analyze the effectiveness of public health expenditure on health status in the selected states.

\section{Methodology}

In this paper the researchers aims to analyse the inter-state disparities in health sector in 15 major States in India selected on the basis of population. The researchers have selected only 15 states because, these selected states alone accounts for about 90 percent of the total population in India and therefore the researchers felt that these 15 states are sufficient to represent the inter-state variations in the country. Alongside, this study focuses on the performance of public health sector of the selected states. This is attempted through a comparative analysis of various parameters depicting health expenditure, availability of health services, their utilization and health outcomes. The researcher has used statistical tools like Standard Deviation, Co-efficient of Variation and Disparity Ratio (Based on model used in Bhattacharya, 2009) to analyse the interstate variations in respect to various health parameters.

\section{Health Profile of Study Area}

The Table 1, presents the population level and a brief health profile of the selected states.

Table 1: Health Profile of the Selected States

\begin{tabular}{|l|l|l|l|l|l|l|l|}
\hline States & $\begin{array}{l}\text { Population } \\
\mathbf{( 2 0 1 1} \\
\text { Census) }\end{array}$ & $\begin{array}{l}\text { Percentag } \\
\text { e in Total } \\
\text { Indian } \\
\text { Population }\end{array}$ & $\begin{array}{l}\text { LEB } \\
\text { (Male } \\
\text { (Men }\end{array}$ & $\begin{array}{l}\text { LEB } \\
\text { (Female } \\
\text { ) }\end{array}$ & IMR & MMR & $\begin{array}{l}\text { Mean of } \\
\text { Rank** } \\
*\end{array}$ \\
\hline Andhra Pradesh & $\begin{array}{l}84580777 \\
(5)\end{array}$ & $\begin{array}{l}6.985 \\
(5)\end{array}$ & $\begin{array}{l}68.4 \\
(11)\end{array}$ & $\begin{array}{l}72.1 \\
(8)\end{array}$ & $\begin{array}{l}39 \\
(9)\end{array}$ & $\begin{array}{l}92 \\
(4)\end{array}$ & $\begin{array}{l}8 \\
(8)\end{array}$ \\
\hline
\end{tabular}




\begin{tabular}{|c|c|c|c|c|c|c|c|}
\hline Assam & $\begin{array}{l}31205576 \\
(14)\end{array}$ & $\begin{array}{l}2.577 \\
(14)\end{array}$ & $\begin{array}{l}65.6 \\
(15)\end{array}$ & $\begin{array}{l}66.8 \\
(15)\end{array}$ & $\begin{array}{l}49 \\
(13)\end{array}$ & $\begin{array}{l}300 \\
(15)\end{array}$ & $\begin{array}{l}14.5 \\
(15)\end{array}$ \\
\hline Bihar & $\begin{array}{l}104099452 \\
\text { (3) }\end{array}$ & $\begin{array}{l}8.597 \\
(3)\end{array}$ & $\begin{array}{l}69.6 \\
(6)\end{array}$ & $\begin{array}{l}70.2 \\
(10)\end{array}$ & $\begin{array}{l}42 \\
(10)\end{array}$ & $\begin{array}{l}208 \\
(9)\end{array}$ & $\begin{array}{l}8.75 \\
(9)\end{array}$ \\
\hline Gujarat & $\begin{array}{l}60439692 \\
(10)\end{array}$ & $\begin{array}{l}4.991 \\
(10)\end{array}$ & $\begin{array}{l}70.7 \\
(2)\end{array}$ & $\begin{array}{l}73.7 \\
\text { (3) }\end{array}$ & $\begin{array}{l}35 \\
(8)\end{array}$ & $\begin{array}{l}112 \\
(5)\end{array}$ & $\begin{array}{l}4.5 \\
(4)\end{array}$ \\
\hline Jharkhand $* *$ & $\begin{array}{l}32988134 \\
\text { (13) }\end{array}$ & $\begin{array}{l}2.724 \\
(13)\end{array}$ & $\begin{array}{l}69.6 \\
(8)\end{array}$ & $\begin{array}{l}70.2 \\
(11)\end{array}$ & $\begin{array}{l}34 \\
(7)\end{array}$ & $\begin{array}{l}208 \\
(10)\end{array}$ & $\begin{array}{l}9 \\
(10)\end{array}$ \\
\hline Karnataka & $\begin{array}{l}61095297 \\
(9)\end{array}$ & $\begin{array}{l}5.045 \\
(9)\end{array}$ & $\begin{array}{l}69 \\
(9)\end{array}$ & $\begin{array}{l}73.5 \\
(5)\end{array}$ & $\begin{array}{l}29 \\
(6)\end{array}$ & $\begin{array}{l}133 \\
(7)\end{array}$ & $\begin{array}{l}6.75 \\
(7)\end{array}$ \\
\hline Kerala & $\begin{array}{l}33406061 \\
(12)\end{array}$ & $\begin{array}{l}2.758 \\
(12)\end{array}$ & $\begin{array}{l}74.2 \\
(1)\end{array}$ & $\begin{array}{l}78.1 \\
(1)\end{array}$ & $\begin{array}{l}12 \\
(1)\end{array}$ & $\begin{array}{l}61 \\
(1)\end{array}$ & $\begin{array}{l}1 \\
(1)\end{array}$ \\
\hline Madhya Pradesh & $\begin{array}{l}72626809 \\
(6)\end{array}$ & $\begin{array}{l}5.997 \\
(6)\end{array}$ & $\begin{array}{l}66.5 \\
\text { (13) }\end{array}$ & $\begin{array}{l}67.3 \\
(14)\end{array}$ & $\begin{array}{l}52 \\
(15)\end{array}$ & $\begin{array}{l}221 \\
(11)\end{array}$ & $\begin{array}{l}13.25 \\
(14)\end{array}$ \\
\hline Maharashtra & $\begin{array}{l}112374333 \\
\text { (2) }\end{array}$ & $\begin{array}{l}9.28 \\
(2)\end{array}$ & $\begin{array}{l}69.9 \\
(5)\end{array}$ & $\begin{array}{l}73.7 \\
(4)\end{array}$ & $\begin{array}{l}22 \\
(3)\end{array}$ & $\begin{array}{l}68 \\
(2)\end{array}$ & $\begin{array}{l}3.5 \\
(2)\end{array}$ \\
\hline Odisha & $\begin{array}{l}41974218 \\
\text { (11) }\end{array}$ & $\begin{array}{l}3.466 \\
(11)\end{array}$ & $\begin{array}{l}66.3 \\
(14)\end{array}$ & $\begin{array}{l}69.6 \\
(12)\end{array}$ & $\begin{array}{l}49 \\
(14)\end{array}$ & $\begin{array}{l}222 \\
(12)\end{array}$ & $\begin{array}{l}13 \\
(13)\end{array}$ \\
\hline Punjab & $\begin{array}{l}27743338 \\
(15)\end{array}$ & $\begin{array}{l}2.291 \\
(15)\end{array}$ & $\begin{array}{l}70.7 \\
\text { (3) }\end{array}$ & $\begin{array}{l}73.8 \\
(2)\end{array}$ & \begin{tabular}{|l|}
24 \\
$(4)$
\end{tabular} & $\begin{array}{l}141 \\
(8)\end{array}$ & $\begin{array}{l}4.25 \\
(3)\end{array}$ \\
\hline Rajasthan & $\begin{array}{l}68548437 \\
(8)\end{array}$ & $\begin{array}{l}5.661 \\
(8)\end{array}$ & $\begin{array}{l}68.6 \\
(10)\end{array}$ & $\begin{array}{l}71.9 \\
(9)\end{array}$ & $\begin{array}{l}46 \\
(11)\end{array}$ & $\begin{array}{l}244 \\
(13)\end{array}$ & $\begin{array}{l}10.75 \\
(11)\end{array}$ \\
\hline Tamil Nadu & $\begin{array}{l}72147030 \\
\text { (7) }\end{array}$ & $\begin{array}{l}5.958 \\
(7)\end{array}$ & $\begin{array}{l}69.6 \\
(7)\end{array}$ & $\begin{array}{l}73 \\
(7)\end{array}$ & $\begin{array}{l}20 \\
(2)\end{array}$ & $\begin{array}{l}79 \\
(3)\end{array}$ & $\begin{array}{l}4.75 \\
(5)\end{array}$ \\
\hline Uttar Pradesh & $\begin{array}{l}199812341 \\
\text { (1) }\end{array}$ & $\begin{array}{l}16.501 \\
(1)\end{array}$ & $\begin{array}{l}67.5 \\
(12)\end{array}$ & $\begin{array}{l}69.2 \\
\text { (13) }\end{array}$ & $\begin{array}{l}48 \\
(12)\end{array}$ & $\begin{array}{l}285 \\
(14)\end{array}$ & $\begin{array}{l}12.75 \\
(12)\end{array}$ \\
\hline West Bengal & $\begin{array}{l}91276115 \\
(4)\end{array}$ & $\begin{array}{l}7.538 \\
(4)\end{array}$ & $\begin{array}{l}70.2 \\
(4)\end{array}$ & $\begin{array}{l}73.3 \\
(6)\end{array}$ & $\begin{array}{l}28 \\
(5)\end{array}$ & $\begin{array}{l}113 \\
(6)\end{array}$ & $\begin{array}{l}5.25 \\
(6)\end{array}$ \\
\hline $\begin{array}{lll}\text { Total } & \text { for } & 15 \\
\text { States } & & \end{array}$ & $\begin{array}{l}109431761 \\
0\end{array}$ & 90.375 & - & - & - & - & - \\
\hline India / Average* & $\begin{array}{l}121085497 \\
7\end{array}$ & 100 & 68.8 & 71.1 & 39 & 167 & - \\
\hline \multicolumn{3}{|c|}{ Standard Deviation } & 2.14 & 2.92 & 12.44 & 79.73 & - \\
\hline \multicolumn{3}{|c|}{ Co-efficient of Variation } & 0.03 & 0.04 & 0.32 & 0.48 & - \\
\hline
\end{tabular}

Source: Population - Census of India 2011; Life Expectancy (2016-2020) - Report of the Technical Group on Population Projections May 2006, National Commission on Population, MOHFW; IMR (2014) - SRS Bulletin, July 2016; MMR (2011-13)-Special bulletin on Maternal Mortality in India, 2011-13, Office of the Registrar General, GoI

Note: Figures in Parenthesis depicts rankings of the respective states

* The all India averages presented in the tables include the data for all the states and UTs in India

** Life Expectancy data for Bihar has been used for Jharkhand ***Mean of Ranks=Life Expectancy of Male Rank + Life Expectancy of Female Rank + IMR Rank + MMR Rank $\div 4$ 
The researchers have used Life Expectancy at Birth (LEB), Infant Mortality Rate (IMR), and Maternal Mortality Rate (MMR) as key health outcomes for the study as they are widely accepted as important indicators of health status of the population. The 'Mean of Ranks' column presents the position of the states in three indicators on the whole. Consistent with the known knowledge, Kerala is at the first rank in all three indicators among all states. The subsequent ranks are held by Maharashtra, Punjab, Gujarat and Tamil Nadu. The moderate positions are held by West Bengal, Karnataka, Andhra Pradesh, Bihar and Jharkhand and the last five positions are held by Rajasthan, Uttar Pradesh, Odisha, Madhya Pradesh and Assam. Assam is in the last position in LEB and MMR while it is at third position from below in IMR. The difference between Kerala and Assam in LEB is 8.6 years for male and 11.3 years for female. Madhya Pradesh is at the last rank in IMR with 52 per 1000 live births which is 4 times more than Kerala with 12 per 1000 live births. The state-wise disparity is seen more in MMR than in IMR with 0.48 and 0.32 co-efficient of variation respectively and the MMR in Assam (300 per 100,000 live births) is 5 times more than in Kerala with 61 per 100,000 live births. The health indicators vary widely across states reflecting the differing levels of resources available and spent for health by the state government which is dealt in the following section.

\section{State-Wise Health Expenditure}

Table 2: Inter-State Disparity in Public Health Expenditure in India

\begin{tabular}{|c|c|c|c|c|c|c|}
\hline States & $\begin{array}{l}\text { Percapita } \\
\text { Public } \\
\text { Health } \\
\text { Expendit } \\
\text { ure (Rs.) } \\
(\mathbf{2 0 0 4 - 0 5 )}\end{array}$ & $\begin{array}{l}\text { Percapita } \\
\text { Public } \\
\text { Health } \\
\text { Expendit } \\
\text { ure (Rs.) } \\
(2014-15)\end{array}$ & $\begin{array}{l}\text { Health } \\
\text { Expendit } \\
\text { ure as } \\
\text { percentag } \\
\text { e of } \\
\text { GSDP } \\
(\%) \\
(2004-05)\end{array}$ & $\begin{array}{l}\text { Health } \\
\text { Expendit } \\
\text { ure as } \\
\text { percentag } \\
\text { e of } \\
\text { GSDP } \\
(\%) \\
(2014-15)\end{array}$ & $\begin{array}{l}\text { Total } \\
\text { State } \\
\text { Expendit } \\
\text { ure on } \\
\text { Health } \\
\text { (Rs. In } \\
\text { Crores) } \\
(\mathbf{2 0 0 4 - 0 5 )}\end{array}$ & $\begin{array}{l}\text { Total } \\
\text { State } \\
\text { Expendit } \\
\text { ure on } \\
\text { Health } \\
\text { (Rs. In } \\
\text { Crores) } \\
\text { 2014-15 }\end{array}$ \\
\hline Andhra Pradesh & $\begin{array}{l}191 \\
(7)\end{array}$ & $\begin{array}{l}1030 \\
(7)\end{array}$ & $\begin{array}{l}0.72 \\
(10)\end{array}$ & $\begin{array}{l}1.92 \\
(1)\end{array}$ & $\begin{array}{l}1516 \\
(3)\end{array}$ & $\begin{array}{l}8920 \\
(4)\end{array}$ \\
\hline Assam & $\begin{array}{l}162 \\
(11)\end{array}$ & $\begin{array}{l}1137 \\
(5)\end{array}$ & $\begin{array}{l}0.86 \\
(8)\end{array}$ & $\begin{array}{l}1.83 \\
(2)\end{array}$ & $\begin{array}{l}454 \\
(14)\end{array}$ & $\begin{array}{l}3626 \\
(13)\end{array}$ \\
\hline Bihar & $\begin{array}{l}93 \\
(15)\end{array}$ & $\begin{array}{l}530 \\
(15)\end{array}$ & $\begin{array}{l}1.12 \\
(1)\end{array}$ & $\begin{array}{l}1.45 \\
(4)\end{array}$ & $\begin{array}{l}826 \\
(11)\end{array}$ & $\begin{array}{l}5411 \\
(10)\end{array}$ \\
\hline Gujarat & $\begin{array}{l}198 \\
(6)\end{array}$ & $\begin{array}{l}1156 \\
(4)\end{array}$ & $\begin{array}{l}0.57 \\
(14)\end{array}$ & $\begin{array}{l}0.8 \\
(11)\end{array}$ & $\begin{array}{l}1067 \\
(8)\end{array}$ & $\begin{array}{l}7131 \\
(6)\end{array}$ \\
\hline Jharkhand & $\begin{array}{l}155 \\
(12)\end{array}$ & $\begin{array}{l}750 \\
(11)\end{array}$ & $\begin{array}{l}0.78 \\
(9)\end{array}$ & $\begin{array}{l}1.14 \\
(7)\end{array}$ & $\begin{array}{l}445 \\
(15)\end{array}$ & $\begin{array}{l}2472 \\
(15)\end{array}$ \\
\hline Karnataka & $\begin{array}{l}233 \\
(3) \\
\end{array}$ & $\begin{array}{l}1043 \\
(6)\end{array}$ & $\begin{array}{l}0.87 \\
(6)\end{array}$ & $\begin{array}{l}0.7 \\
(14) \\
\end{array}$ & $\begin{array}{l}1290 \\
(6)\end{array}$ & $\begin{array}{l}6416 \\
(7)\end{array}$ \\
\hline Kerala & $\begin{array}{l}287 \\
(1)\end{array}$ & $\begin{array}{l}1437 \\
(1)\end{array}$ & $\begin{array}{l}0.88 \\
(5)\end{array}$ & $\begin{array}{l}0.97 \\
(9)\end{array}$ & $\begin{array}{l}943 \\
(9)\end{array}$ & $\begin{array}{l}5082 \\
(11)\end{array}$ \\
\hline Madhya Pradesh & $\begin{array}{l}145 \\
(13) \\
\end{array}$ & $\begin{array}{l}722 \\
(12)\end{array}$ & $\begin{array}{l}0.87 \\
(7) \\
\end{array}$ & $\begin{array}{l}1.14 \\
(8)\end{array}$ & $\begin{array}{l}937 \\
(10)\end{array}$ & $\begin{array}{l}5504 \\
(9) \\
\end{array}$ \\
\hline Maharashtra & $\begin{array}{l}204 \\
(5)\end{array}$ & $\begin{array}{l}931 \\
(9)\end{array}$ & $\begin{array}{l}0.55 \\
(15)\end{array}$ & $\begin{array}{l}0.61 \\
(15)\end{array}$ & $\begin{array}{l}2090 \\
(2)\end{array}$ & $\begin{array}{l}10973 \\
(2)\end{array}$ \\
\hline
\end{tabular}




\begin{tabular}{|l|l|l|l|l|l|l|}
\hline Odisha & $\begin{array}{l}183 \\
(9)\end{array}$ & $\begin{array}{l}913 \\
(10)\end{array}$ & $\begin{array}{l}0.98 \\
(2)\end{array}$ & $\begin{array}{l}1.19 \\
(6)\end{array}$ & $\begin{array}{l}701 \\
(12)\end{array}$ & $\begin{array}{l}3832 \\
(12)\end{array}$ \\
\hline Punjab & 247 & 1001 & 0.65 & 0.78 & 632 & 2873 \\
& $(2)$ & $(8)$ & $(13)$ & $(12)$ & $(13)$ & $(14)$ \\
\hline Rajasthan & 186 & 1303 & 0.98 & 1.52 & 1128 & 9311 \\
& $(8)$ & $(2)$ & $(3)$ & $(3)$ & $(7)$ & $(3)$ \\
\hline Tamil Nadu & 223 & 1162 & 0.71 & 0.73 & 1433 & 8001 \\
& $(4)$ & $(3)$ & $(11)$ & $(13)$ & $(5)$ & $(5)$ \\
\hline Uttar Pradesh & 128 & 665 & 0.92 & 1.36 & 2280 & 14159 \\
& $(14)$ & $(13)$ & $(4)$ & $(5)$ & $(1)$ & $(1)$ \\
\hline West Bengal & 173 & 665 & 0.69 & 0.82 & 1448 & 6140 \\
& $(10)$ & $(14)$ & $(12)$ & $(10)$ & $(4)$ & $(8)$ \\
\hline India / Average & 242 & 973 & 0.84 & 0.98 & 26,313 & 121600 \\
\hline Standard Deviation & 48.83 & 257.99 & 0.16 & 0.41 & 543.44 & 3204.81 \\
\hline Co-efficient & 0.2 & 26.51 & 0.19 & 42.1 & 0.02 & 2.64 \\
Variation & & & & & & \\
\hline Disparity Ratio & 80.165 & 93.21 & 67.86 & 133.6 & 6.97 & 9.611 \\
\hline Source: Percapita Pubn
\end{tabular}

Source: Percapita Public Health Expenditure, Health Expenditure as percentage of GSDP (\%),

Total State Expenditure on Health (2014-15) - National Health Profile 2017, GoI;

Data for 2004-05 - National Health Accounts India, GoI

Note: Calculation of Disparity ratio $(\%)=[($ Maximum Value-Minimum Value $) \div$ Average Value]*100

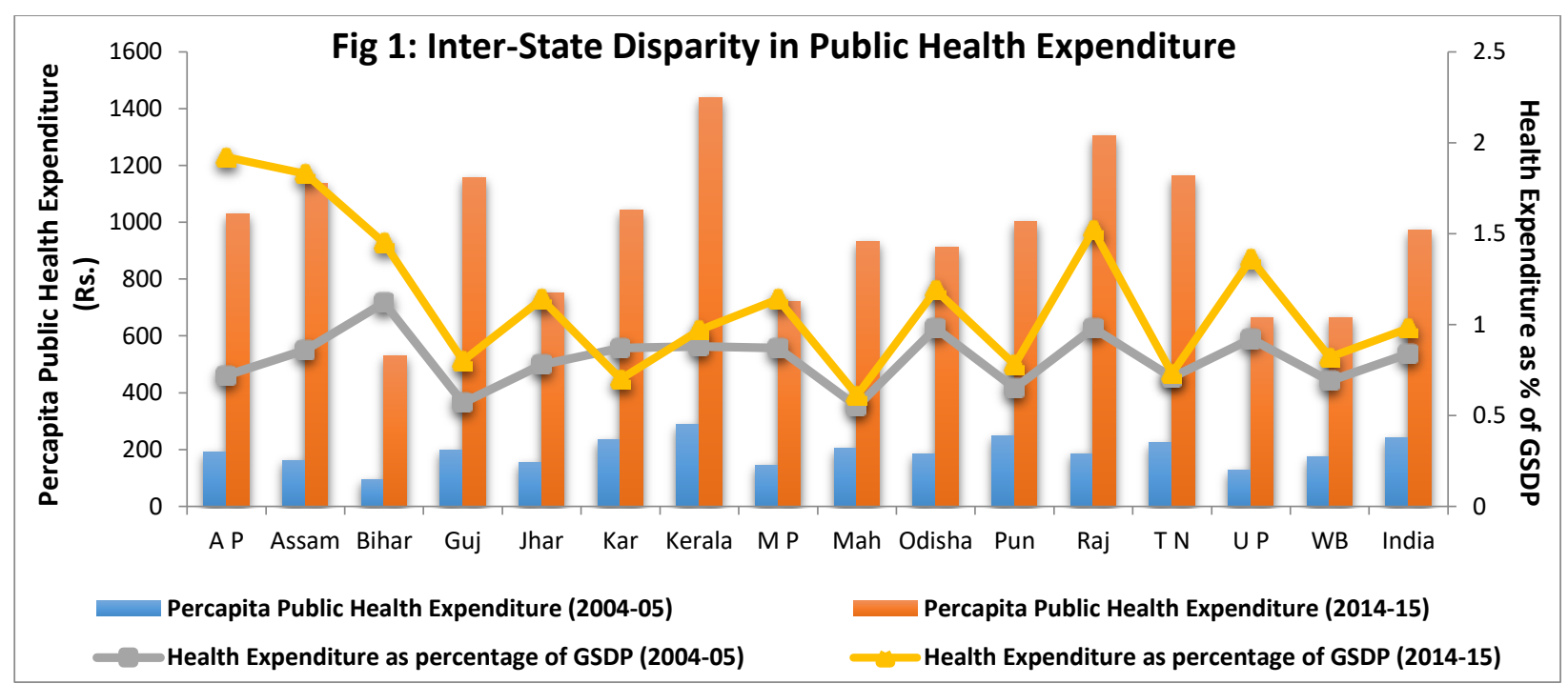

Source: Based on Table 2

Public Health Expenditure is an important determinant of the health status of the population and higher public health expenditure is generally associated with better health outcomes (Barenberg et al., 2015) (Deolalikar et al., 2008). Table 2 and Figure 1, shows the inter-state variations in public health expenditure during 2004-05 and 2014-15 which helps to know the decadal growth as well. At both time points Kerala has spent the highest per capita health expenditure while the lowest amount was spent by Bihar. Being the most populated state with more than 19 crore population Uttar Pradesh has spent the highest level of Total Health Expenditure but slips to $14^{\text {th }}$ 
rank (2004-05) and $13^{\text {th }}$ rank (2014-15) when it comes to expenditure per person. Despite being the $3^{\text {rd }}$ most populated state Bihar has spent substantially lesser than other states with lesser population and stands in $11^{\text {th }}$ position in terms of Total Health Expenditure and the same goes to Odisha and Jharkhand as well. It is important to note that, states like Kerala, Gujarat, Maharashtra, Punjab and Tamil Nadu have made larger expenditure per person for health (Table 2) and holds top five ranks in health status indicators (Table 1) have spent relatively less in terms of percentage to GSDP. Interestingly states like Assam, Bihar, Odisha, Madhya Pradesh, Rajasthan and Uttar Pradesh which shows abysmal performance in health outcome and spends less per capita health expenditure have spent larger amount for health in terms of percentage to GSDP. These attributes indicates the level of effectiveness of expenditure made by the states which is reflected in the health status of the respective states.

\section{Availability of Public Health Services}

Table 3: Inter-State Disparity in Availability of Public Health Services in India

\begin{tabular}{|c|c|c|c|c|c|c|}
\hline States & $\begin{array}{l}\text { Average } \\
\text { Populatio } \\
\text { n Served } \\
\text { Per Govt. } \\
\text { Hospital }\end{array}$ & $\begin{array}{l}\text { Average } \\
\text { Populatio } \\
\text { n Served } \\
\text { Per Govt. } \\
\text { Hospital } \\
\text { Bed } \\
\end{array}$ & $\begin{array}{l}\text { Average } \\
\text { populatio } \\
\text { n served } \\
\text { per Govt. } \\
\text { Allopathi } \\
\text { c Doctor }\end{array}$ & $\begin{array}{l}\text { Total } \\
\text { Number } \\
\text { of Govt. } \\
\text { Hospital } \\
\text { S }\end{array}$ & $\begin{array}{l}\text { Total } \\
\text { Numbe } \\
\text { r of } \\
\text { Govt. } \\
\text { Hospita } \\
\text { l Beds }\end{array}$ & $\begin{array}{l}\text { Total } \\
\text { Number } \\
\text { of Govt. } \\
\text { Allopathi } \\
\text { c Doctors }\end{array}$ \\
\hline Andhra Pradesh & $\begin{array}{l}312778 \\
(15)\end{array}$ & $\begin{array}{l}4381 \\
(12)\end{array}$ & $\begin{array}{l}19699 \\
(12)\end{array}$ & $\begin{array}{l}278 \\
(14)\end{array}$ & $\begin{array}{l}19848 \\
(9)\end{array}$ & $\begin{array}{l}4414 \\
(8)\end{array}$ \\
\hline Assam & $\begin{array}{l}27874 \\
(4)\end{array}$ & $\begin{array}{l}2369 \\
(8)\end{array}$ & $\begin{array}{l}7201 \\
(2)\end{array}$ & $\begin{array}{l}1137 \\
(6)\end{array}$ & $\begin{array}{l}13381 \\
(11)\end{array}$ & $\begin{array}{l}4401 \\
(9)\end{array}$ \\
\hline Bihar & $\begin{array}{l}70701 \\
(7)\end{array}$ & $\begin{array}{l}8789 \\
(14)\end{array}$ & $\begin{array}{l}28391 \\
(15)\end{array}$ & $\begin{array}{l}1436 \\
(4)\end{array}$ & $\begin{array}{l}11552 \\
(13)\end{array}$ & $\begin{array}{l}3576 \\
(13)\end{array}$ \\
\hline Gujarat & $\begin{array}{l}159297 \\
(11)\end{array}$ & $\begin{array}{l}2196 \\
(7)\end{array}$ & $\begin{array}{l}17036 \\
(10)\end{array}$ & $\begin{array}{l}385 \\
(13)\end{array}$ & $\begin{array}{l}27928 \\
(8)\end{array}$ & $\begin{array}{l}3600 \\
(12)\end{array}$ \\
\hline Jharkhand & $\begin{array}{l}59682 \\
(6)\end{array}$ & $\begin{array}{l}6052 \\
(13)\end{array}$ & $\begin{array}{l}19786 \\
(13)\end{array}$ & $\begin{array}{l}549 \\
(11) \\
\end{array}$ & $\begin{array}{l}5414 \\
(14) \\
\end{array}$ & $\begin{array}{l}1656 \\
(15)\end{array}$ \\
\hline Karnataka & $\begin{array}{l}93599 \\
(9)\end{array}$ & $\begin{array}{l}1154 \\
(4)\end{array}$ & $\begin{array}{l}13290 \\
(8)\end{array}$ & $\begin{array}{l}654 \\
(9)\end{array}$ & $\begin{array}{l}53022 \\
(4)\end{array}$ & $\begin{array}{l}4606 \\
(7)\end{array}$ \\
\hline Kerala & $\begin{array}{l}27588 \\
(3)\end{array}$ & $\begin{array}{l}918 \\
(2)\end{array}$ & $\begin{array}{l}6762 \\
(1)\end{array}$ & $\begin{array}{l}1278 \\
(5)\end{array}$ & $\begin{array}{l}38400 \\
(6)\end{array}$ & $\begin{array}{l}5214 \\
(5)\end{array}$ \\
\hline Madhya Pradesh & $\begin{array}{l}167659 \\
(12)\end{array}$ & $\begin{array}{l}2683 \\
(11)\end{array}$ & $\begin{array}{l}15341 \\
(9)\end{array}$ & $\begin{array}{l}451 \\
(12)\end{array}$ & $\begin{array}{l}28187 \\
(7)\end{array}$ & $\begin{array}{l}4929 \\
(6)\end{array}$ \\
\hline Maharashtra & $\begin{array}{l}200323 \\
(13)\end{array}$ & $\begin{array}{l}715 \\
(1)\end{array}$ & $\begin{array}{l}27790 \\
(14)\end{array}$ & $\begin{array}{l}585 \\
(10)\end{array}$ & $\begin{array}{l}163865 \\
\text { (1) }\end{array}$ & $\begin{array}{l}4217 \\
(11)\end{array}$ \\
\hline Odisha & $\begin{array}{l}23884 \\
(2)\end{array}$ & $\begin{array}{l}2505 \\
(10)\end{array}$ & $\begin{array}{l}9729 \\
(6)\end{array}$ & $\begin{array}{l}1750 \\
(2)\end{array}$ & $\begin{array}{l}16683 \\
(10)\end{array}$ & $\begin{array}{l}4296 \\
(10)\end{array}$ \\
\hline Punjab & $\begin{array}{l}119033 \\
(10)\end{array}$ & $\begin{array}{l}2420 \\
(9)\end{array}$ & $\begin{array}{l}9153 \\
(4)\end{array}$ & $\begin{array}{l}240 \\
(15)\end{array}$ & $\begin{array}{l}11804 \\
(12)\end{array}$ & $\begin{array}{l}3121 \\
(14)\end{array}$ \\
\hline Rajasthan & $\begin{array}{l}22566 \\
(1)\end{array}$ & $\begin{array}{l}1521 \\
(6)\end{array}$ & $\begin{array}{l}9010 \\
(3)\end{array}$ & $\begin{array}{l}3145 \\
(1)\end{array}$ & $\begin{array}{l}46669 \\
(5)\end{array}$ & $\begin{array}{l}7877 \\
(3)\end{array}$ \\
\hline Tamil Nadu & 87124 & 1069 & 9564 & 788 & 64243 & 7178 \\
\hline
\end{tabular}




\begin{tabular}{|l|l|l|l|l|l|l|}
\hline & $(8)$ & $(3)$ & $(5)$ & $(8)$ & $(3)$ & $(4)$ \\
\hline Uttar Pradesh & $\begin{array}{l}254172 \\
(14)\end{array}$ & NA & $\begin{array}{l}19561 \\
(11)\end{array}$ & $\begin{array}{l}831 \\
(7)\end{array}$ & NA & $\begin{array}{l}10798 \\
(1)\end{array}$ \\
\hline West Bengal & $\begin{array}{l}58697 \\
(5)\end{array}$ & $\begin{array}{l}1170 \\
(5)\end{array}$ & $\begin{array}{l}10411 \\
(7)\end{array}$ & $\begin{array}{l}1566 \\
(3)\end{array}$ & $\begin{array}{l}78566 \\
(2)\end{array}$ & $\begin{array}{l}8829 \\
(2)\end{array}$ \\
\hline India / Average & 61011 & 1833 & 11528 & 20306 & 675779 & 106415 \\
\hline Standard Deviation & 89408.86 & 2278.89 & 7034.01 & 761.44 & $\begin{array}{l}41464.5 \\
4\end{array}$ & 2406.81 \\
\hline $\begin{array}{l}\text { Co-efficient } \\
\text { Variation }\end{array}$ & 1.47 & 1.24 & 0.61 & 0.04 & 0.06 & 0.02 \\
\hline Disparity Ratio of & 475.67 & 440.48 & 187.62 & 14.31 & 23.45 & 8.59 \\
\hline
\end{tabular}

Source: National Health Profile, GoI

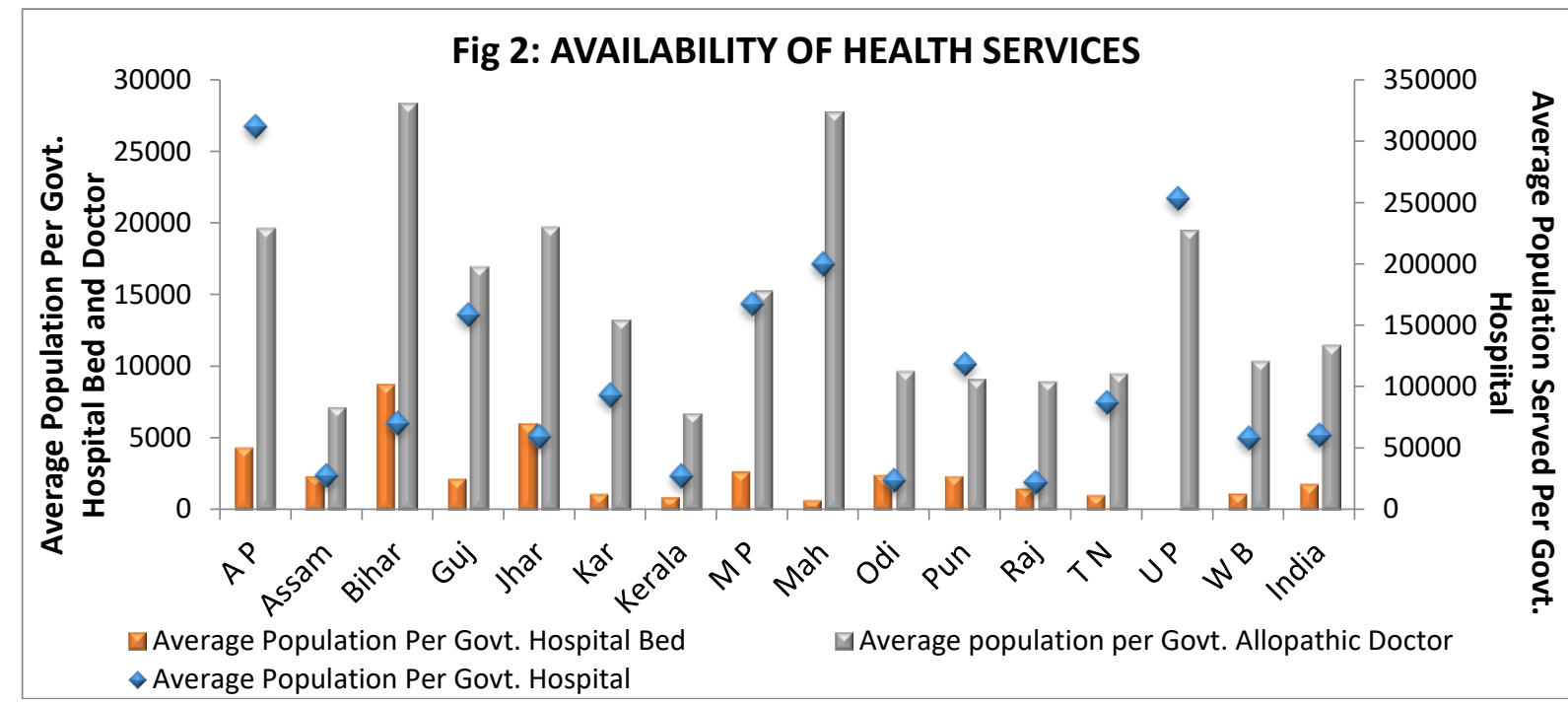

Source: Same as Table 3

Due to differences in capacity to allocate resources to the health sector there are differences in the availability of health services, which can be seen in Table 3 and Fig 2. The co-efficient of variation and disparity ratio depicts larger divergence in the variables of Average population served per Government Hospital, Bed and Doctor than the variables of Number of Government Hospitals, Beds and Doctors in the states. While the population size vary widely from state to state, the existence of larger disparity in variables of Average population served per Government Hospital, Bed and Doctor reflects severe disparity in availability of health services which portrays the undesirable situation of inequality in India. At the same time the ultimate objective for health care provision is not necessarily to make available increased number of hospitals, doctors and other health facilities, but rather to provide quality health services as these resources are the means towards the end of providing the best possible services. For example despite having comparatively lesser number of Government Hospitals, Beds and Doctors, Kerala stands in better position in Average population served per Government Hospital, Bed and Doctor and also has exceptional health status (Table 1). This portrays the effectiveness of health expenditure and health system in the state. Followed by Kerala, Rajasthan has performed fairly well in availability of health services but it is not reflected in the health status of the people in the state 
(Table 1). Further, the state of Andhra Pradesh shows miserable ranking positions in all parameters of availability of health services despite having good rankings in expenditure indicators (Table 2). These both situations are examples of lack of effectiveness and efficiency of public health system and its expenditure.

\section{Utilization of Public Health Services}

The percentage of treatment received from government sources which shows the utilization of Public Health Services for Non-Hospitalised (outpatient) and Hospitalised (inpatient) ailments during 2004 and 2014 in rural and urban areas of selected states have been depicted in the Table 4 as follows.

Table 4: Percentage of Treatment from Government Sources

\begin{tabular}{|c|c|c|c|c|c|c|c|c|}
\hline \multirow[t]{3}{*}{ States } & \multicolumn{4}{|c|}{$\begin{array}{l}\text { Percentage of Non-Hospitalised } \\
\text { Treatment from Govt. Sources }\end{array}$} & \multicolumn{4}{|c|}{$\begin{array}{l}\text { Percentage of Hospitalised } \\
\text { Treatment from Govt. Sources }\end{array}$} \\
\hline & \multicolumn{2}{|c|}{ Rural } & \multicolumn{2}{|c|}{ Urban } & \multicolumn{2}{|c|}{ Rural } & \multicolumn{2}{|c|}{ Urban } \\
\hline & 2004 & 2014 & 2004 & 2014 & 2004 & 2014 & 2004 & 2014 \\
\hline Andhra Pradesh & $\begin{array}{l}21 \\
(8)\end{array}$ & $\begin{array}{l}16 \\
(13)\end{array}$ & $\begin{array}{l}20 \\
(8)\end{array}$ & $\begin{array}{l}12 \\
(14)\end{array}$ & $\begin{array}{l}27 \\
(13)\end{array}$ & $\begin{array}{l}23 \\
(13)\end{array}$ & $\begin{array}{l}36 \\
(7)\end{array}$ & $\begin{array}{l}22 \\
(13)\end{array}$ \\
\hline Assam & $\begin{array}{l}27 \\
(6)\end{array}$ & $\begin{array}{l}84 \\
(1)\end{array}$ & $\begin{array}{l}24 \\
(3)\end{array}$ & $\begin{array}{l}44 \\
(2)\end{array}$ & $\begin{array}{l}74 \\
(3)\end{array}$ & $\begin{array}{l}89 \\
(1)\end{array}$ & $\begin{array}{l}55 \\
(4)\end{array}$ & $\begin{array}{l}52 \\
(4)\end{array}$ \\
\hline Bihar & $\begin{array}{l}5 \\
(15)\end{array}$ & $\begin{array}{l}14 \\
(15)\end{array}$ & $\begin{array}{l}11 \\
(14)\end{array}$ & $\begin{array}{l}12 \\
(15)\end{array}$ & $\begin{array}{l}14 \\
(15)\end{array}$ & $\begin{array}{l}43 \\
(6)\end{array}$ & $\begin{array}{l}22 \\
(15)\end{array}$ & $\begin{array}{l}39 \\
(6)\end{array}$ \\
\hline Gujarat & $\begin{array}{l}21 \\
(9)\end{array}$ & $\begin{array}{l}24 \\
(9)\end{array}$ & $\begin{array}{l}18 \\
(10)\end{array}$ & $\begin{array}{l}15 \\
(9)\end{array}$ & $\begin{array}{l}31 \\
(10)\end{array}$ & $\begin{array}{l}23 \\
(14)\end{array}$ & $\begin{array}{l}26 \\
(13)\end{array}$ & $\begin{array}{l}23 \\
(12)\end{array}$ \\
\hline Jharkhand & $\begin{array}{l}13 \\
(13)\end{array}$ & $\begin{array}{l}32 \\
(6)\end{array}$ & $\begin{array}{l}24 \\
(4)\end{array}$ & $\begin{array}{l}15 \\
(10)\end{array}$ & $\begin{array}{l}47 \\
(6)\end{array}$ & $\begin{array}{l}40 \\
(7)\end{array}$ & $\begin{array}{l}31 \\
(9)\end{array}$ & $\begin{array}{l}26 \\
(11)\end{array}$ \\
\hline Karnataka & $\begin{array}{l}34 \\
(4)\end{array}$ & $\begin{array}{l}26 \\
(8)\end{array}$ & $\begin{array}{l}16 \\
(12)\end{array}$ & $\begin{array}{l}14 \\
(13)\end{array}$ & $\begin{array}{l}40 \\
(8)\end{array}$ & $\begin{array}{l}27 \\
(12)\end{array}$ & $\begin{array}{l}29 \\
(11)\end{array}$ & $\begin{array}{l}18 \\
(15)\end{array}$ \\
\hline Kerala & $\begin{array}{l}37 \\
(3)\end{array}$ & $\begin{array}{l}36 \\
(5)\end{array}$ & $\begin{array}{l}22 \\
(6)\end{array}$ & $\begin{array}{l}31 \\
(3)\end{array}$ & $\begin{array}{l}36 \\
(9)\end{array}$ & $\begin{array}{l}35 \\
(9)\end{array}$ & $\begin{array}{l}35 \\
(8)\end{array}$ & $\begin{array}{l}33 \\
(7)\end{array}$ \\
\hline Madhya Pradesh & $\begin{array}{l}23 \\
(7)\end{array}$ & $\begin{array}{l}29 \\
\text { (7) }\end{array}$ & $\begin{array}{l}23 \\
(5)\end{array}$ & $\begin{array}{l}24 \\
(6)\end{array}$ & $\begin{array}{l}59 \\
\text { (4) }\end{array}$ & $\begin{array}{l}54 \\
(4)\end{array}$ & $\begin{array}{l}49 \\
(5)\end{array}$ & $\begin{array}{l}42 \\
(5)\end{array}$ \\
\hline Maharashtra & $\begin{array}{l}16 \\
(11)\end{array}$ & $\begin{array}{l}20 \\
(11)\end{array}$ & $\begin{array}{l}11 \\
(15)\end{array}$ & $\begin{array}{l}15 \\
(11)\end{array}$ & $\begin{array}{l}29 \\
(11)\end{array}$ & $\begin{array}{l}19 \\
(15)\end{array}$ & $\begin{array}{l}28 \\
(12)\end{array}$ & $\begin{array}{l}20 \\
(14)\end{array}$ \\
\hline Odisha & $\begin{array}{l}51 \\
(1)\end{array}$ & $\begin{array}{l}76 \\
(2)\end{array}$ & $\begin{array}{l}54 \\
(1)\end{array}$ & $\begin{array}{l}54 \\
(1)\end{array}$ & $\begin{array}{l}79 \\
(1)\end{array}$ & $\begin{array}{l}81 \\
(2)\end{array}$ & $\begin{array}{l}73 \\
(1)\end{array}$ & $\begin{array}{l}58 \\
(1)\end{array}$ \\
\hline Punjab & $\begin{array}{l}16 \\
(12)\end{array}$ & $\begin{array}{l}17 \\
(12)\end{array}$ & $\begin{array}{l}18 \\
(11)\end{array}$ & $\begin{array}{l}23 \\
\text { (7) }\end{array}$ & $\begin{array}{l}29 \\
(12)\end{array}$ & $\begin{array}{l}29 \\
\text { (11) }\end{array}$ & $\begin{array}{l}26 \\
(14)\end{array}$ & $\begin{array}{l}30 \\
(8)\end{array}$ \\
\hline Rajasthan & $\begin{array}{l}44 \\
(2)\end{array}$ & $\begin{array}{l}44 \\
\text { (3) }\end{array}$ & $\begin{array}{l}53 \\
(2)\end{array}$ & $\begin{array}{l}29 \\
\text { (4) }\end{array}$ & $\begin{array}{l}52 \\
(5)\end{array}$ & $\begin{array}{l}54 \\
(5)\end{array}$ & $\begin{array}{l}64 \\
\text { (3) }\end{array}$ & $\begin{array}{l}54 \\
(2)\end{array}$ \\
\hline Tamil Nadu & $\begin{array}{l}29 \\
(5)\end{array}$ & $\begin{array}{l}42 \\
\text { (4) }\end{array}$ & $\begin{array}{l}22 \\
\text { (7) }\end{array}$ & $\begin{array}{l}29 \\
\text { (5) }\end{array}$ & $\begin{array}{l}41 \\
\text { (7) }\end{array}$ & $\begin{array}{l}40 \\
(8)\end{array}$ & $\begin{array}{l}37 \\
(6)\end{array}$ & $\begin{array}{l}29 \\
(9)\end{array}$ \\
\hline Uttar Pradesh & $\begin{array}{l}10 \\
(14)\end{array}$ & $\begin{array}{l}15 \\
(14)\end{array}$ & $\begin{array}{l}13 \\
\text { (13) }\end{array}$ & $\begin{array}{l}16 \\
(8)\end{array}$ & $\begin{array}{l}27 \\
(14)\end{array}$ & $\begin{array}{l}30 \\
(10)\end{array}$ & $\begin{array}{l}31 \\
(10)\end{array}$ & $\begin{array}{l}28 \\
(10)\end{array}$ \\
\hline West Bengal & 19 & 23 & 20 & 15 & 79 & 77 & 65 & 53 \\
\hline
\end{tabular}




\begin{tabular}{|l|l|l|l|l|l|l|l|l|}
\hline & $(10)$ & $(10)$ & $(9)$ & $(12)$ & $(2)$ & $(3)$ & $(2)$ & $(3)$ \\
\hline India & 22 & 28 & 19 & 21 & 42 & 42 & 38 & 32 \\
\hline Standard Deviation & 12.76 & 21.22 & 13 & 12.43 & 20.41 & 22.38 & 16.44 & 13.6 \\
\hline Co-efficient of Variation & 0.58 & 0.76 & 0.68 & 0.59 & 0.49 & 0.53 & 0.43 & 0.43 \\
\hline Disparity Ratio & 209.09 & 250 & 226.32 & 200 & 154.76 & 166.67 & 134.21 & 125 \\
\hline
\end{tabular}

Note: Figures shown in Parenthesis indicates the rankings of respective states

The NSS data in Table 4 shows that the inter-state disparities in terms of co-efficient of variation and disparity ratio have increased for both non-hospitalised and hospitalised treatments in rural areas, whereas the variation have declined in urban areas for the same. In both rural and urban areas more people have received treatment from government services for hospitalised treatment compared to non-hospitalised ailments. The table interprets that more than 70 percent of nonhospitalised and 60 percent of hospitalised treatments were taken from private health services despite its higher costs. In spite of Government Hospitals accepting patients of all backgrounds and all degrees of criticality the heavy dependence on private services signifies that the government hospitals are not capable of handling the people seeking treatment from them.

\section{Findings}

Summary of the major findings from the study have been plotted down:

- Kerala is the only state which stands top in all respects like public health expenditure, Availability and Utilisation of Government health services and also exemplary health status as well.

- Meanwhile, states like Bihar, Jharkhand and Uttar Pradesh have very low public health expenditure, deficit in availability of government health services and poor utilisation of public health services and the health status is also in worrisome state. For example, having more than 19 crore population, Uttar Pradesh has only 831 Government Hospitals which means one hospital for every 2.5 lakhs people (Table 3 ) which is unacceptable by all means.

- This vicious circle implies that the economic conditions, health finance and infrastructure at the state level have direct bearing on the health outcomes.

- Another important finding worth noting is, ironically states which holds top five positions in health status i.e., Kerala, Maharashtra, Punjab, Gujarat and Tamil Nadu (Table 1) have considerably utilised lesser percentage of government health services (Table 4). Whereas, states like Assam, Odisha and Madhya Pradesh which has inferior health status and holds last 3 positions in health status rankings (Table 1) have almost 50 percentage of treatment took place in Government hospitals. This ironic situation leads to the interpretation that states using more of private health services have better health outcome which implies the lack of effectiveness of public health system and expenditure in our states.

\section{Suggestions}

The high utilisation of private health services points more to the failure of the public sector to provide necessary health services and is a reflection of lack of adequate infrastructure at public 
health facilities, inefficient public health administration and delivery of quality services. To overcome these deficiencies, the researchers have proposed the following suggestions:

- The first step is to expand the public provision and overcome the problem of staff and infrastructure constraints. It is therefore, important to augment public spending on healthcare and target the increased spending on low-income states where the health spending is abysmally low.

- Special policy packages for developing health infrastructure can be provided by Central Government to the states with deficient health expenditure and infrastructure to improve the accessibility, availability, affordability and utilization of public health services.

- Immediate actions must be taken to fill up the vacancies at Government Hospitals, especially in rural areas where large number of posts remain vacant (Rural Health Statistics 2016, GoI)

- Alongside, the public system is beset with lack of involvement, devotion and commitment of those who are employed which leads to inefficiency in health services. Since private sector is directly accountable to the patients they make greater efforts to provide quality health care which is missing in public sector. Public health personnel must be made accountable and answerable by taking necessary actions for the complaints against any negligence (if found true) on part of them.

- Government at both central and state level have to look into the defects at administrative, regulatory and institutional framework and make necessary proactive policy changes to improve the effectiveness and get optimal benefits from the existing set-up of health system.

These suggestions will support for achieving Universal Health Coverage which aims at the following outcome:

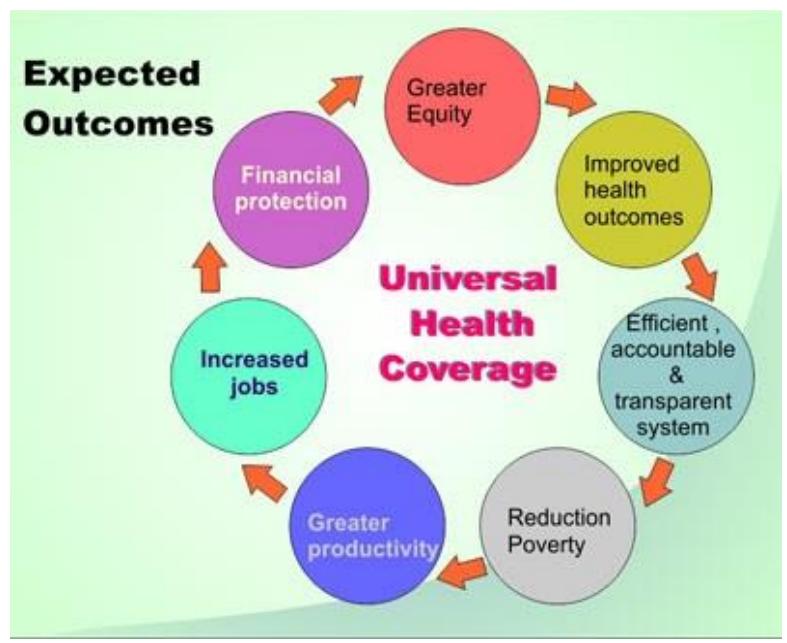

Source: National Health Portal, GoI

\section{Conclusion}

It may be concluded that the economic conditions, health finance, infrastructure and public administration at the state level have direct bearing on the health outcome of the states and this has largely led to regional disparities in health status. With vast disparity in access to, 
availability, affordability and effectiveness of healthcare services across different states, it is essential to take necessary corrective measures targeting to reduce the disparity to achieve better and equitable health services for All leading to Universal Health Coverage of citizens in India which is the real inclusiveness.

\section{References}

[1] Barenberg, Andrew; Basu, Deepankar; and Soylu, Ceren. (2015). "THE EFFECT OF PUBLIC HEALTH EXPENDITURE ON INFANT MORTALITY: EVIDENCE FROM A PANEL OF INDIAN STATES, 1983-84 TO 2011-12", Economics Department Working Paper Series Paper 199.

[2] Bhattacharya, Govind. (2009) "INTRA-STATE DISPARITY IN GOVERNMENT EXPENDITURE:AN ANALYSIS", Economic and Political Weekly, vol 44 nos 26 \& 27

[3] Central Bureau of Health Intelligence. (2015). "NATIONAL HEALTH PROFILE 2015", MoHFW, GoI

[4] Central Bureau of Health Intelligence. (2017). "NATIONAL HEALTH PROFILE 2017", MoHFW, GoI

[5] Deolalikar Anil, Dean Jamison, Prabhat Jha and Ramanan Laxminarayan. (2008). "FINANCING HEALTH IMPROVEMENTS IN INDIA", Health Affairs, Vol. 27, No. 4

[6] Gumber, Anil and Dhak, Biplab and Lalitha, N.(2011). "DECLINING FREE HEALTHCARE AND RISING TREATMENT COSTS IN INDIA: AN ANALYSIS OF NATIONAL SAMPLE SURVEYS 1986-2004", Journal of Health Management, Vol. 14 No.2

[7] MoHFW. (2006). "REPORT OF THE TECHNICAL GROUP ON POPULATION PROJECTIONS 2006", National Commission on Population, GoI

[8] MoHFW. (2016). "RURAL HEALTH STATISTICS 2015-16", Statistics Division, MoHFW, GoI

[9] MoHFW: "NATIONAL HEALTH PORTAL" MoHFW, GoI Retrieved from http://www.nhp.gov.in/universal-health-coverage

[10] National Health Accounts Cell. (2009). "NATIONAL HEALTH ACCOUNTS, INDIA 200405", MoHFW, GoI

[11] NSSO. (2006). "MORBIDITY, HEALTH CARE AND CONDITION OF THE AGED", NSS 60th Round (January - June 2006), NSSO, MoSPI , GoI

[12] NSSO. (2015). "KEY INDICATORS OF SOCIAL CONSUMPTION IN INDIA: HEALTH", NSS 71st Round (January - June 2014), NSSO, MoSPI, GoI

[13] RGI. (2013). "SPECIAL BULLETIN ON MATERNAL MORTALITY IN INDIA, 2011-13", Office of Registrar General, Ministry of Home Affairs, GoI

[14] RGI. (2016). "SRS BULLETIN 2014", Office of Registrar General, Ministry of Home Affairs, GoI

[15] www.censusindia.gov.in

*Corresponding author.

E-mail address: 1.ganesan2008@ yahoo.com/ veena.senthamizh@ gmail.com 